\title{
Determinants of Commercial Banks' Lending Behavior in Nepal
}

\author{
Bishnu Prasad Bhattarai, PhD \\ Academic Director/ Business Unit Head \\ Excel Business College, Pokhara University \\ New Baneshwor, Kathmandu, Nepal \\ Tel: +977-1-4485109 \\ Cell: +977-9851103366 \\ Email: bishnu.bhattarai@excelcollege.edu.np
}

\begin{abstract}
The main objective of this study was to establish the determinants of lending operations among commercial banks in Nepal. Specifically, the study sought to explore the effect of bank specific characteristics and to identify external factors that determine commercial banks' lending behavior in Nepal. Secondary panel data was used that covered a period of six years (2012/13-2017/18) of the major ten commercial banks to examine factors associated with lending behavior of in Nepal. From the estimation results, it was found that liquidity ratio, interest rate spread and exchange rate were significant in determining lending behavior in Nepal's commercial banks. The positive effect of exchange rate infers that commercial banks in Nepal have sufficient insights into the international market and trade and that they are prepared to meet short-term and long-term commitments. Inflation maintained by the central economic policy has a positive and significant influence on lending volumes among commercial banks in Nepal. Likewise, the findings showed interest rate spread negatively and significantly on total loans advanced to individual and institutions. This implies that as the cost of borrowing increases, banks significantly increase credit supply in the market. However, there seems a greater deal of reluctance from among the borrowers to get more credit in such situations. During periods of economic stagnation, majority of loans become non-performing and thus constraining credit available to private sector.
\end{abstract}

Keywords: Loans and Advances, Interest Rate Spread and Cash Reserve Ratio, Inflation Rate and Exchange Rate

\section{Introduction}

Commercial banks are significant in the overall performance of an economy and acts as a financial intermediate. Commercial banks have been at the center of driving the economy as evidenced through the tremendous growth in the private sector credit over time (Olokoyo, 2011). According to Jamil (1988) and Beck, Demirguc-Kunt and Maksimovic (2004) if bank credit is not available, the expansion of productive investments in manufacturing, agriculture, real estate development, distribution, fishing, trade, tourism etc. would in many cases be impossible. Moreover, productive units would be forced to maintain larger working capital balances to meet fluctuating requirements for funds. This is uneconomical since large sums would have to be held idle for some periods while during seasonal peaks of business activity, such sums might be insufficient.

However, according to King (1986), regulation is necessary to check excessive credit creation. The economy needs adequate but not excessive supply of money, which might result in high inflation. On the other hand, if money supply lags behind production rates, the economy may suffer from deflation with equally undesirable effects (Celikoz and Arslan, 2011). Government's monetary policy instruments seek to ensure an optimal money supply commensurate with the national objectives of stable prices, sound economic growth and high employment.

Overall, it is evident that financial intermediation involving mobilization of funds from cash surplus economic agents to cash deficit agents to finance productive investment and therefore productivity is crucial in determining the pace of economic growth and development (Levine, 2004).

In developing country commercial banks are very important of the financial approach. They always concern about how to make funds and how they lending and investing to their borrowers. Financial institutions provide capital to the entrepreneurs for the development of industry, trade and business by investing saving collected as deposits. They also providing good services to their customers, facilitating their economic activities, thus, integrated and speedy 
development of the country is only possible. When competitive and reliable banking services are developed and carried to every hook and corner of the country.

One of the basic objectives of establishing a commercial bank is to earn optimal profit by proper utilization of fund. By mobilizing public money and channeling the same to various business and production activities. Commercial banks contribute to the development of the country. In a developing country like Nepal, saving is low and scatters in small amounts which individuals residing in different corners of the country. Mobilization of such savings is made by commercial banks through their branches established in different parts of the country.

\section{Empirical Review}

There is vast empirical literature on the factors associated with lending behavior among commercial banks.

Vazakidis and Adamopoulos (2009) have investigated the relationship between economic growth and credit market development in Italian market. The log-linear regression model indicated a positive effect of economic growth on credit market development. Further, the authors established that through the transmission mechanism, a rise in prime rate negatively affects banks' lending behaviour. This affirms a previous study whereby bank credit expansions lean to be pro-cyclical; that is, high rates of growth in GDP induce a high rate of growth in bank credit. This is due to the fact that in the period of economic boom, banks loosen up their criteria and lend to both good and bad projects, while in times of economic depression most loans become non-performing and thus constraining credit available to private sector.

Karim et. al., (2011) have examined the effects of monetary policy channel on the banks' lending for Malaysian market using the data covering the period 1993 to 2008. From the OLS results, bank liquidity was shown to be core and significant in determining the supply of loans by banks. This is in tandem with the earlier study which conclude that during the 2008 financial crises, banks were ultimately faced by liquidity stress hence capping their lending ability. There exists a pro-cyclical relationship between economic growth and bank lending because in periods of economic recession, demand for credit plummets.

Olokoyo (2011) has studied the determinants of the commercial banks' lending behaviour in Nigeria for the period 1980 - 2005. The study used fixed effects regression model. From the study result, it was found out that a long-run relationship existed between banks' lending, deposits, interest rate, minimum cash reserve requirement, investment portfolio, ratio of liquidity, foreign exchange and gross domestic product. Specifically, lending rates were found to influence banks' lending performance despite being unpronounced. These affirms the finding by Karim et al (2011) who investigates the impacts of interest rates on the banks' lending in Malaysian context and contend that interest rates negatively affect lending among the banks while controlling for macroeconomic variables such as GDP and inflation.

Ngomsi and Djiogap (2012) have investigated the determinants of bank long-term lending behavior in the Central African Economic and Monetary Community. The study applied Ordinary Least Square (OLS) as an estimation technique. From the study results, it was revealed that ownership of a bank is core in determining the total loan and advances extended by a bank. The study revealed that foreign banks tend to exhibit higher long-term loan ratios compared to the state owned.

Olumuyiwa et. al., (2012) have explored the link between banks deposits and total loans advanced by commercial banks using OLS. The study results indicated a positive impact of deposits on the commercial banks' lending volumes. This was supported by the findings of McCathy et al. (2010) who found out the presence of a positive effect of customer deposits on the banks' lending. Similarly, another study found that demand deposits liabilities had the most significant positive effect on the banks' credit allocations in the Nigerian credit market.

It is debated that a big balance sheet allows managers to invest more in different geographical and business segments to address the issues of asymmetric shocks. In a study conducted by Obamuyi (2013) has revealed that the banks size measured by total assets and bank capitalization influenced commercial lending behaviors and the likelihood of long term lending. The author suggests that large banks have an advantage in providing a large variety of financial services to their clients since they are capable of mobilizing more funds. Regarding the magnitude of the bank, Cole et al (2004) have found out that small banks adopt small business loan underwriting practices that are riskier than those of larger banks which ultimately determine the available credit to the public. 
Irungu, (2013) has explored effect of interest rate spread on financial performance of commercial banks in Kenya. The study collected data from all 43 commercial banks in Kenya. A multiple linear regression model was adopted. It was revealed that a strong positive and significant relationship between financial performance of commercial banks and interest rate spread. It was shown that interest rate spread affect performance asset in banks since it raised cost of borrowers.

Malede (2014) has explored determinants of commercial banks' lending in the Ethiopian banking industry using panel data from eight banks for the period between 200 and 2011. The results of the study indicate a significant relationship between banks' lending and banks size, credit risk, gross domestic product and liquidity ratios. On contrary, the study found out that deposit, investments, cash reserve ratios and interest rates had no significant effect on Ethiopian banks' lending activities.

Bhattarai (2016) has examined the effect of credit risk on performance of selected 14 commercial banks of Nepal for the period between 2010 and 2015. He has used the descriptive and causal comparative research designs as well as regression model. His study indicated that banks performance was directly positively affected by variable like bank size, credit risk indicators and cost per loan assets. The same study, however, did not find any relationship between banks' performance with the capital adequacy ratio and cash reserve. In contrast, the non-performing loan ratio seemed to have affected the performance of the bank in negative way.

Timsina (2016) has conducted a study to evaluate the banks' lending operations and its drivers using time series analysis, Ordinary Least Square Regression techniques and empirical analysis. This has perhaps been the most comprehensive study conducted of this type using all the commercial banks and for the duration of 1975-2014. She has found that liquidity ratio of the banks, in addition to the Gross Domestic Product, has hugely affected the lending operations of the commercial banks. Upon performing the Granger Causality Test, she recorded that there is a unidirectional causal relationship from GDP to private sector credit. She has also implied that the GDP should be the barometer of the economy which is to be closely observed by the commercial banks while making adjustment to their lending operations.

\section{Conceptual Framework}

The review of both theoretical and empirical literature indicates that most of the studies on the banks' lending behavior have been carried out in the developed financial markets. Studies reviewed have been used the total loan and advance, Volume of deposits of Banks, investment portfolio. Lending rate, cash reserve ratio, liquidity ratio, credit risk, interest rate spread, capital structure and exchange rate as dependent and independent variables (Olokonyo,2011; Olumuyiwa, 2012 and Malede,2014).

There are however, a few studies Olokonyo (2011) and Olumuyiwa (2012) have been done in the less developed financial markets. Similarly, studies on the determinants of lending behavior of banks in the Nepali financial market are hardly available with the only existing one only addressing a few variables by Bhattarai (2016) and Timsina ( 2016). Majority of studies conducted in Nepal focus on the determinants of interest rate spreads among the commercial banks by Bhattarai (2016 and Timsina (2016). This study intends to fill the empirical as well as the methodological gap since most studies including the one done in Nepal without addressing the relevant estimation bias. This study thus employed panel data analysis technique in estimation which is more dynamic compared to cross-sectional and time series data. Further, necessary tests were undertaken to validate the estimates.

Therefore, it is concluded that for fixed deposit also, there is no substitution effect at all. Thesis from predecessors and related books and journals were collected, studied and reviewed for the literature review. This could not be the sufficient study even I have made my possible effort to bring the best study as far as my capability. This study includes the variables like interest rate spread, exchange rate, liquidity ratio and inflation and their interrelationships. Moreover, the study will also focus on the behavior of the lending from the commercial banks along with the changes in these explanatory variables. I want to prove that this research is an original and one should be the foundation for the future researchers to know about the assessment of these variables of Commercial Banks and their impact on lending operations. Future researchers are requested to research about the different factors influencing interest rate like maturity period, capital adequacy, growth in the national economy in terms of Gross Domestic Product (GDP), volume of deposits, size of the bank etc.

With the literature review a conceptual framework for this study is developed by exploring the relationship between the dependent variable (Loans and Advances), bank specific variables (Interest Rate Spread and Cash 
Reserve Ratio) and macroeconomic variables (inflation rate and exchange rate). The conceptual framework of the study, therefore, is presented hereby in the following figure.

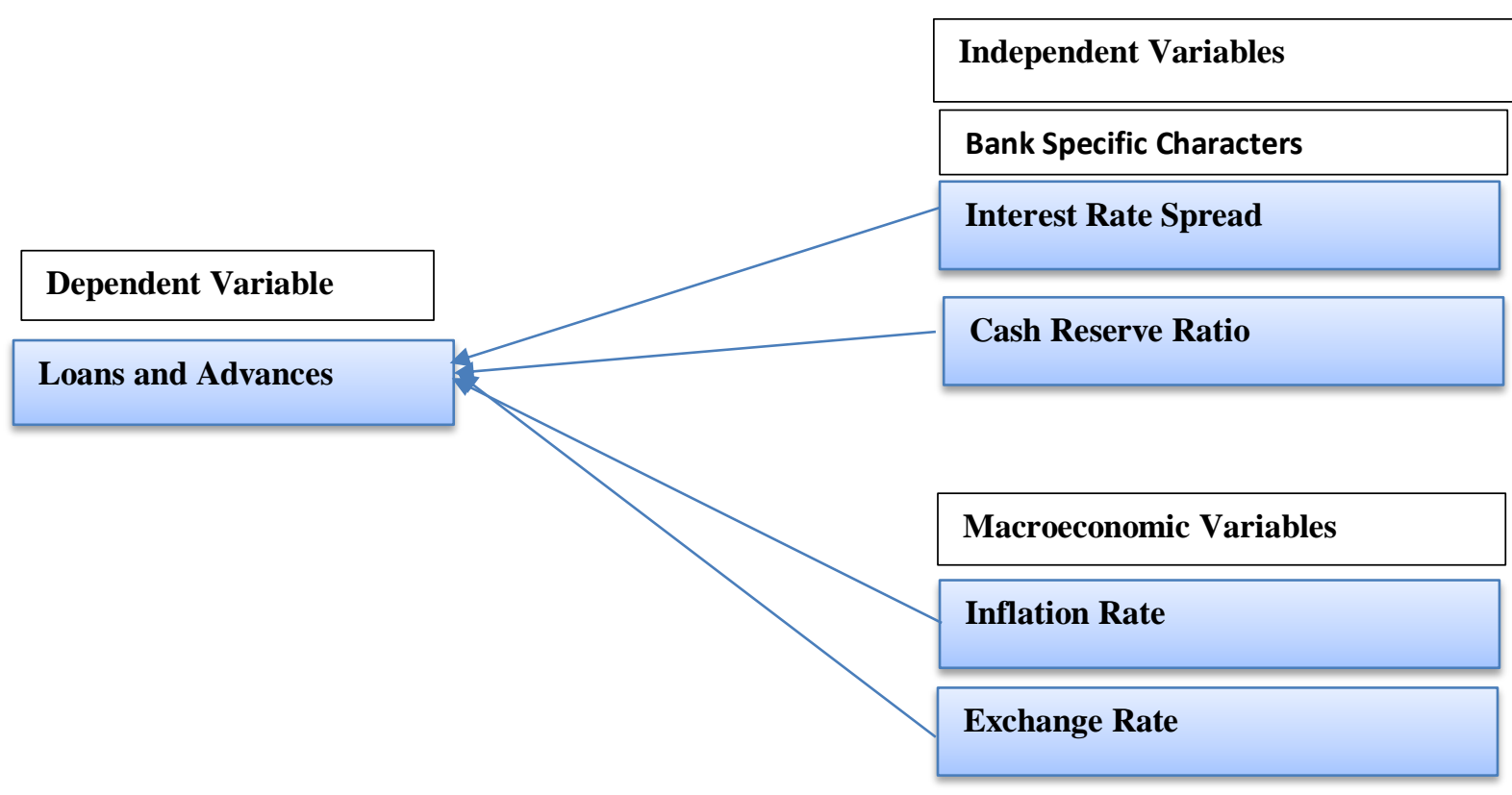

Figure 1: Conceptual Framework

Source: Conceptual Framework Developed by Researcher (2019)

\section{Research Methodology}

This study is based on the secondary data of ten sample commercial banks over the period of six fiscal years starting from 2012/13 till 2017/18. The data in general were of two major sources of origin i.e. bank related variables and macroeconomic variables. The bank related variables have been obtained from the annual reports of the commercial banks sampled for this study. In contrast, the macroeconomic data have been collected from the monetary policy and economic surveys conducted by Nepal Rastra Bank every year during the years we have studied. The variable for which data have been collected are total loans and advances of the sampled banks, average interest rate spread, cash reserve ratio or statutory liquidity ratio, exchange rate and inflation rate.

A sample of 10 commercial banks has been taken out of 28 commercial banks. Moreover, in selecting the banks for the study due care has been given to include the mixture of joint venture and private banks, best performers as well as average performer.

Table 1: Banks Selected for the Study

\begin{tabular}{llll}
\hline SN & Name of the Bank & Study Period & Observations \\
\hline 1 & Nepal Investment Bank Limited & $2012 / 13-2017 / 18$ & 6 \\
\hline 2 & Nabil Bank Limited & $2012 / 13-2017 / 18$ & 6 \\
\hline 3 & Bank of Kathmandu Limited & $2012 / 13-2017 / 18$ & 6 \\
\hline 4 & Mega Bank Limited & $2012 / 13-2017 / 18$ & 6 \\
\hline 5 & NIC Asia Bank Limited & $2012 / 13-2017 / 18$ & 6 \\
\hline 6 & Himalayan Bank Limited & $2012 / 13-2017 / 18$ & 6 \\
\hline 7 & Nepal Bangladesh Bank Limited & $2012 / 13-2017 / 18$ & 6 \\
\hline 8 & Standard Chartered Bank Limited & $2012 / 13-2017 / 18$ & 6 \\
\hline 9 & Everest Bank Limited & $2012 / 13-2017 / 18$ & 6 \\
\hline 10 & Nepal SBI Bank Limited & $2012 / 13-2017 / 18$ & 6 \\
\hline Total & & & 60 \\
\hline
\end{tabular}


These commercial banks are very popular in the market. There are many other commercial banks; samples cover only two because ownership of the bank, size of the capital and establishment period is taken into consideration. All these banks in the sample are operating for more than 10 years. So, these both banks are competitors. Therefore, owing to future impacts of these banks on Nepali money market, they have been selected for study in interest rate structure and its impact on lending.

\subsection{The Model}

This study adopted the model employed by Olokoyo (2011) and Malede (2014) where all commercial banks are considered for the defined period of time i.e. six years. The model captures how different bank specific variables as well as macroeconomic variables feed into the overall bank lending operations. The study specified a model linking factors influencing lending behavior of commercial banks which includes bank specific characteristics and macroeconomic variables. For the vector of banks specific variables, we have interest rates spread, liquidity ratio, inflation ratio, and exchange rate.

The empirical model is defined as shown below:

\section{LnLoansit $=\alpha+\beta_{1} I R S_{i t}+\beta_{2} S L R_{i t}+\beta_{3} E X R_{i t}+\beta_{4} I n f_{i t}+\varepsilon_{i t}$}

Where:

$\alpha=$ Intercept/constant term

LnLoans $=$ Natural logarithm of the total loans and advances

IRS = Interest rate spread

$\boldsymbol{S L R}=$ Statutory liquidity ratio or the cash reserve requirement

$\boldsymbol{E X R}=$ Exchange rate on the last day of the each reporting fiscal year

Inf = Inflation rate indicated by the economic survey

$\varepsilon_{i t}=$ error term of the stochastic model

Betas $(\beta)$ are the parameters of the models

In addition, we note that $i=1,2,3 \ldots \ldots 10$ since we are analyzing ten commercial banks while $t=1,2 \ldots .6$ since our analysis captures six years from 2012/13 - 2017/18.

\subsection{Variables and Hypothesis}

In this study total loans and advances is taken as dependent variable and bank specific variables (interest rate spread and cash reserve ratio) and macroeconomic variables (inflation rate and exchange rate) are taken as explanatory or independent variables.

\subsubsection{Dependent Variable}

A variable is said to be dependent variable if its values depend upon other variables. The purpose is to study, analyze and predict the variability in the dependent variable. The dependent variable of this study is total loans and advances.

\section{Loans and Advances}

Loans and advances are explained in terms of the commercial banks' lending part of their deposits in the form of a number of credit schemes. In addition, the amount lent by the lender to the borrower for a specific purpose like the construction of the building, capital requirements, purchase of machinery and so on, for a particular period of time is known as Loan. In general, loans are granted by the banks and financial institutions. It is an obligation which needs to be repaid back after the expiry of the stipulated period. The loan carries an interest rate on the debt advanced. Before advancing loans, the lending institution checks the credit report of the customer, to know about his credibility, financial position and capacity to pay. Loan is classified as secured or unsecured based on security or demand, time or instalment loan based on the repayment mode or home, vehicle, commercial, educational etc. based on the purpose it has been rendered. Likewise, advances are the source of finance, which is provided by the banks to the companies to meet the short-term financial requirement. It is a credit facility which should be repaid within one year as per the terms, conditions and norms issued by Nepal Rastra Bank for lending and also by the schemes of the 
concerned bank. They are granted against securities which are as under either primary security or collateral security or guarantees. In addition, bank advances are either short term loans, overdraft, cash-credit or bills purchased.

\subsubsection{Independent Variables}

A variable is called independent variable if its vale is not influenced by any other variable under the study. Any change in independent variable rather leads to changes in the dependent variables. Thus, the independent variables are those, which are used as basis of prediction and the dependent variable is the variable that is being predicted. The study has been used bank specific and macroeconomic variables.

\section{Bank Specific Variables}

\section{Interest Rate Spread (IRS)}

In this respect, Timsina (2016) has found significant negative relationship between interest rate spread and total bank lending in the study. The study found out that as the interest rate spread tend to increase, either to enjoy the luxury granted by the central bank or in exploit the economic benefit of the less competitive market. Likewise, Bhattarai (2018) also indicated that interest rate spread has significant negative relationship with the investment portfolio of the commercial banks of Nepal. The interest rate spread measures the effectiveness of the bank in the intermediation function, where the bank borrows the fund at a lower rate of interest while, the same time, lend at higher level of interest rate. The spread also used to identify the intensity of competition among banks in the market. Higher positive interest rate spread shows the successfulness of the bank in collecting the funds at cheaper rate and granting them at higher rate. The higher interest rate spread is not possible for most banks in the time of strong competition. In this case bank management seeks to look for other new revenue generating services to its clients to make up the decreased spread. The interest rate spread is the differences in interest rate between the lending rate and its deposit rate. Based on the earlier empirical evidence-based research and studies, this study develops the following hypothesis:

\section{$H_{1}$ : Interest rate spread has a significant and negative impact on loans and advances}

\section{Cash Reserve Ratio (CRR)}

Cash Reserve Ratio (CRR) is the percentage of deposits which commercial banks are required to keep as cash according to the directions of the central bank. The reserve ratio is an important tool of the monetary policy of an economy and plays an essential role in regulating the money supply. When the central bank wants to increase money supply in the economy, it lowers the reserve ratio. As a result, commercial banks have higher funds to disburse as loans, thereby increasing the money supply in an economy. On the other hand, for controlling inflation, the CRR is generally increased, thereby decreasing the lending power of banks, which in turn reduces the money supply in an economy. Based on the evidences this study develops the following hypothesis:

\section{$\mathrm{H}_{2}$ : Cash Reserve Ratio (CRR) has significant and negative impact on loans and advances}

\section{Macroeconomic Variables}

\section{Inflation Rate (INF)}

Inflation is a quantitative measure of the rate at which the average price level of a basket of selected goods and services in an economy increases over a period of time. It is the constant rise in the general level of prices where a unit of currency buys less than it did in prior periods. Often expressed as a percentage, inflation indicates a decrease in the purchasing power of a nation's currency.

As prices rise, a single unit of currency loses value as it buys fewer goods and services. This loss of purchasing power impacts the general cost of living for the common public which ultimately leads to a deceleration in economic growth. The consensus view among economists is that sustained inflation occurs when a nation's money supply growth outpaces economic growth. To combat this, a country's appropriate monetary authority, like the central bank, then takes the necessary measures to keep inflation within permissible limits and keep the economy running smoothly. Inflation is measured in a variety of ways depending upon the types of goods and services considered, and is the opposite of deflation which indicates a general decline occurring in prices for goods and services when the inflation rate falls below 0 percent. Based on the theoretical framework and empirical studies carried out earlier, this study develops the following hypothesis: 
$\mathrm{H}_{3}$ : The inflation rate has significant and negative impact on loans and advances

\section{Exchange Rate}

An exchange rate is the value of one nation's currency versus the currency of another nation or economic zone. For example, how many U.S. dollars does it take to buy one euro? Exchange rates can be Free Floating meaning it rises and falls due to changes in the foreign exchange market or Restricted Currencies where in some countries have restricted currencies, limiting their exchange to within the countries' borders. Also, a restricted currency can have its value set by the government. Example of this can be evidenced in the exchange rate patterns between the currencies of Nepal and India. Similar to this is Currency Peg in which a country will peg its currency to that of another nation. Likewise, the exchange rate can be Onshore vs. Offshore where exchange rates can also be different for the same country. In some cases, there is an onshore rate and an offshore rate. Generally, a more favorable exchange rate can often be found within a country's border versus outside its borders.

In addition, exchange rate can be either Spot or. Forward where the exchange rates can have what is called a spot rate, or cash value, which is the current market value. Alternatively, an exchange rate may have a forward value, which is based on expectations for the currency to rise or fall versus its spot price. Forward rate values may fluctuate due to changes in expectations for future interest rates in one country versus another. Based on the studies carried out earlier this study develops the hypothesis as follows:

\section{$H_{4}$ : Exchange rate has significant and positive impact on loans and advances}

\section{Result and Conclusion}

\subsection{Descriptive Statistics}

Table 2 shows that the average of total loan and advances, which for convenience of the analysis of the rest of the processes has been transformed logarithmically normally, was Rs. 52,684 million with a minimum of Rs 11,729 million and a maximum of Rs. 121,032 million. This huge range implies that the variables exhibit variability given the variance in the specified basic descriptive statistics. Statutory Liquidity Ratio and Interest Rate Spread were on average 16.0 percent and 4.4 percent with a standard deviation of 8.0 and 0.7 respectively. On assessing the Exchange Rate, the study found out that over time, the minimum exchange rate reported was Rs. 95.90 for each US Dollar and the highest reported was Rs. 109.94.

Table 2: Descriptive Statistics of the Study Variables

\begin{tabular}{|c|c|c|c|c|c|c|}
\hline Variables & Scale & $\mathbf{N}$ & Minimum & Maximum & Mean & Std. Deviation \\
\hline LOA & Rs. Million & 60 & 11729.00 & 121031.56 & 52683.68 & 26432.13 \\
\hline IRS & $\%$ & 60 & 2.80 & 7.09 & 4.42 & 0.72 \\
\hline SLR & $\%$ & 60 & 5.49 & 37.52 & 15.94 & 7.97 \\
\hline$\overline{E R}$ & Rs. & 60 & 95.90 & 109.94 & 102.11 & 5.22 \\
\hline INF & $\%$ & 60 & 4.50 & 9.90 & 7.75 & 2.05 \\
\hline
\end{tabular}

Source: Results are drawn from SPSS 23.0

Further, the inflation rate also varied during these six years' period between the lowest of 4.5 percent and the highest of 9.9 percent with the average of 7.75 percent and the standard deviation of 2.05 percent.

The results of the table above show that variation in the loan and advances over these years under the study. The major reason behind this is largely due to the relatively short history of some of the banks e.g. Mega Bank Limited which grew remarkably during the latter years in the study (Mega, 2018). In contrast the volume of lending of relatively established banks like Nabil Bank Limited and Nepal Investment Bank Limited were already high and way above the levels of the rest of the banks. This could consequently lead to skewed presentation of the analysis of the data and hence these values have been logarithmically transformed to their normal base of e and is used for the further analysis e.g. correlation and regression. 


\subsection{Correlation Analysis}

Correlation analysis is used to determine the extent of the correlation of different pairs of variables under study. It measures/calculates the correlation coefficient between 1 and -1 . This further predicts presence or absence of multicollinearity which is considered to exist when there is perfect linear relationship between the variables under the study. The correlation matrix was used to determine if any pair of independent variables was highly collinear through the magnitude of the correlation coefficient of the pairs of variables established. This bias arises when one or more pairs of independent variables are perfectly correlated to each other. Most pairs were found to be highly correlated leading multicollinearity.

Table 3: Correlation Matrix of Study Variables ( $N=60)$

\begin{tabular}{lccccc}
\hline Variables & LnLOA & IRS & SLR & ER & INF \\
\hline LnLOA & 1 & & & & \\
\hline IRS & -.088 & 1 & & & \\
\hline SLR & -.020 & .117 & 1 & 1 & \\
\hline ER & $.612^{* *}$ & -.234 & -.230 &. $.440^{* * *}$ & 1 \\
\hline INF & $-.465^{* * *}$ & .154 & .051 &
\end{tabular}

**. Correlation is significant at the 0.01 level (2-tailed).

*. Correlation is significant at the 0.05 level (2-tailed).

Source: Results are drawn from SPSS 23.0

According to Kennedy (2008), multicollinearity becomes a problem if the correlation coefficient is more than 0 . The data collected during the study was subjected to Pearson correlation analysis. As indicated in Table 3, the study found that a pair had a correlation of more than 0.5 which is the threshold to permit retaining of those variables. Therefore, to correct the same, the LOA has, as mentioned earlier, been transformed to its log linear normal for further analysis. For the rest of the variables, the correlation analysis showed mixed results. The liquidity ratio seemed to have slightly negatively correlated with the exchange rate, interest rate spread and loan and advances. This means that as the liquidity ratio tends to increase, there seems to be an evidence of exchange rate, interest rate spread and loan and advance to recede. Similar results were recorded during the study conducted by Bhattarai (2016) where he found that liquidity ratio correlated negatively with the capital reserve and bank size, somehow collaborating indicators to exchange rates and interest rate spread. In contrast, Eke (2015) reported from his study in Nigeria that there seems to be higher IRS only when there are trends of increasing exchange rate and interest rate spread but with decreasing inflation. This phenomenon could better be conceptualized with the affinity of the borrowers towards low risk of inflation as the major investment these days have, in one way or the other, related to international trade and market. Likewise, the exchange rate of the local currency i.e. Nepali Rupees to that of US dollars seemed to have strong positive correlation with the amount of loans and investment $(p>0.01)$ meaning there is a greater chance that had the rate of exchange a dollar can fetch in terms of local currency, there is a strong tendency of the borrowers/customers to get loans from the commercial banks.

\subsection{Regression Analysis}

The lending operations of the selected commercial banks has been studied as a component of cause and effect relationship using regression techniques. The table below is the summary of such relationships that exist for each of the determinants or the drivers of the lending operations in these banks as a product of multiple regression modelling adopting the empirical model that has been mentioned in the third chapter using the statistical software IBM Statistics SPSS Version 23.0. The table 4 showcase the coefficients of exchange rate and that of the volume of lending to be highly significant with the level of significance below 0.01 indicating that with every unit change in the exchange rate the volume of the lending and the behavior of the banks in reciprocating such change in their lending operations is evident in almost all cases. In terms of interest rate spread and liquidity rate there exist a good degree of direct and positive relationship with that of the volume of credit. However, these relationships could not be qualified as statistically significant owing to their $\mathrm{P}$ values slightly above the threshold of 0.05 . In a study carried out in 2016 by Timsina, she also discovered that the exchange rates have positive impact on the private sector credit which she deemed as theoretically correct though the impacts measured were not significant in statistical terms. 
In yet another study conducted in Nigeria, the results were different for exchange rate in defining the volume of lending by the commercial banks owing to variation in terms of regulation put as statutory provisions in putting forth the interest rates by the central banks (Eke et. al., 2015). Their results indicate that the relationship of the exchange rate with that of the volume of lending is negatively proportional to the exchange rate while there was a regulated provision in governing the rates of interest while at the same time the opposite phenomenon becomes visible when there is a deregulated provision put forth by the central bank.

Table 4: Determinants of Lending of Sample Commercial Banks in Nepal

\begin{tabular}{|c|c|c|c|c|c|c|}
\hline \multirow[t]{2}{*}{ Variables } & \multirow[t]{2}{*}{ Coefficients } & \multirow[t]{2}{*}{ Std. Error } & \multirow[t]{2}{*}{$\mathbf{t}$} & \multirow[t]{2}{*}{ Sig. } & \multicolumn{2}{|c|}{ Collinearity Statistics } \\
\hline & & & & & Tolerance & VIF \\
\hline Constant & 18.945 & 1.469 & 12.897 & .000 & & \\
\hline IRS & .048 & .078 & .620 & .538 & .937 & 1.067 \\
\hline SLR & .007 & .007 & 1.058 & .295 & .939 & 1.065 \\
\hline ER & .057 & .012 & 4.655 & .000 & .742 & 1.348 \\
\hline INF & -.064 & .030 & -2.132 & .037 & .801 & 1.249 \\
\hline
\end{tabular}

Source: Results are drawn from SPSS 23.0

In contrast, the rate of inflation has shown negative relationship with the lending operation of the commercial banks. This means that the banks tend to keep their volume of lending low whenever there seems that inflation to be higher or in increasing trend. Though there could not be seen any significance of the relationship statistically, the table 4 suggest that there seems the negative coefficient of -0.068 . Similar results were obtained during her studies of Timsina (2016). She has also indicated that inflation has negative impact on the real private sector credit and also supported the result as theoretically correct despite the fact that the coefficient was again not significant statistically. In her study, she had indicated that liquidity ratio as the key indicator for the commercial banks to invariably look for. In general, inverse relationship between banks' liquid assets to both lending operations as well deposit is visible. This is evident with the stricken capacity of the banks in expanding the credit whenever the central bank puts on obligation for the increased liquidity of assets.

\section{Summary and Conclusion}

The importance of banking industry is demonstrated by the growth of financial sector in relation to growth of the entire economy. The banking industry in Nepal has grown tremendously. Lending, through interest rates on loans and advances, is fundamental for this growth and it is a major source of the bank's income. Equally, the industry has faced shocks such as the credit crunch that led to compulsory merger among the banks. The main objective of this study was to establish the determinants of lending operations among commercial banks in Nepal. Specifically, the study sought to explore the effect of bank specific characteristics and to identify external factors that determine commercial banks' lending behavior in Nepal. Secondary panel data was used that covered a period of six years (2012/13-2017/18) of the major ten commercial banks to examine factors associated with lending behavior of in Nepal. From the estimation results, it was found that liquidity ratio, interest rate spread and exchange rate were significant in determining lending behavior in Nepal's commercial banks. The positive effect of exchange rate infers that commercial banks in Nepal have sufficient insights into the international market and trade and that they are prepared to meet short-term and long-term commitments. Inflation maintained by the central economic policy has a positive and significant influence on lending volumes among commercial banks in Nepal. Likewise, the findings showed interest rate spread negatively and significantly on total loans advanced to individual and institutions. This implies that as the cost of borrowing increases, banks significantly increase credit supply in the market. However, there seems a greater deal of reluctance from among the borrowers to get more credit in such situations. During periods of economic stagnation, majority of loans become non-performing and thus constraining credit available to private sector. 
This study concentrated on exploring the determinants of lending behavior of the commercial banks in Nepal with a focus on bank and external factors. There is need for consideration of more other factors in future studies like political environment as well as other socioeconomic environment. Other aspects of apex management including the diligence of board of directors and firm characteristics are essential. Similar comparative study is required in different trading blocs like the comparative studies with that of the neighboring countries especially those belonging to SAARC region among others.

\section{References}

Bhattarai B.P. (2018). Impact of bank specific and macroeconomic variables on investment of commercial banks in Nepal. International Journal of Management and Applied Science, 4(4), 8-13.

Bhattarai, Y.R. (2016). Effect of credit risk on the performance of Nepalese commercial banks. NRB Economic Review, 28(1), 41-64.

Cole, R. A., Goldberg, L. G., \& White L. J., (2004). Cookie-cutter versus character. The micro structure of small business lending by large and small banks. Journal of Financial and Quantitative Analysis, 39(2), $227-251$.

Eke, F.A., Eke, I.C. \& Inyand O.G. (2015). Interest rate and commercial banks' lending operations in Nigeria: A structural break analysis using Chow Test. Global Journal of Social Sciences, 14, 9-22

Karim, A., Azman-Saini, Z. W. \& Abdul, K, B. (2011). Bank lending channel of monetary policy. Journal of AsiaPacific Business, 12(3), 225-243.

Malede, M (2014). Determinants of commercial Banks lending: Evidence from Ethiopian commercial banks. Journal of Business and Management, 6(20), 31-46.

Nepal Rastra Bank (2018). Banking and Financial Statistics. Kathmandu. Banking and Financial Institution Regulation Department, Statistics Department.

Ngomsi, A \& Djiogap, F. (2012). Determinants of bank long-term lending behavior in the Central African Economic and Monetary Community (CEMAC). Review of Economics \& Finance, 107-114.

Obamuyi T.M. (2013). An Analysis of the deposits and lending behaviors of banks in Nigeria. International Journal of Engineering and Management Sciences, 4(1), 46-54.

Obamuyi, T.M. (2013). Factors influencing investment decisions in capital market: A study of individual investors in Nigeria. Organizations and Market in Emerging Economies 4(1), 141-161.

Olokoyo, F. O. (2011). Determinants of commercial Banks' lending behavior in Nigeria. International Journal of Financial Research 2(2), 61-72.

Olumuyiwa, O. S., Oluwatosin, O. A. \& Chukwuemeka, O. E. (2012). Determinants of lending behavior of commercial banks: Evidence from Nigeria, a co-integration analysis. Journal of Humanities and Social Science, 5(5), 71-80.

Olweny, T. and Shipho, T.M (2011). Effects of banking sectoral factors on the profitability of commercial banks in Kenya. Economics and Finance Review, 1(5), 01 - 30.

Timsina, N. (2016). Determinants of bank lending behavior in Nepal. The International Journal of Business and Management 4(8), 64-77.

\section{Copyrights}

Copyright for this article is retained by the author(s), with first publication rights granted to the journal.

This is an open-access article distributed under the terms and conditions of the Creative Commons Attribution license (http://creativecommons.org/licenses/by/4.0/) 